Article

\title{
Effect of Silica Fume and Fly Ash Admixtures on the Corrosion Behavior of AISI 304 Embedded in Concrete Exposed in 3.5\% $\mathrm{NaCl}$ Solution
}

\author{
Miguel Angel Baltazar-Zamora ${ }^{1, *}$, David M. Bastidas ${ }^{2}$, Griselda Santiago-Hurtado ${ }^{3}$, \\ José Manuel Mendoza-Rangel ${ }^{4}$ (D), Citlalli Gaona-Tiburcio ${ }^{5}$, José M. Bastidas ${ }^{6}(\mathbb{D}$ \\ and Facundo Almeraya-Calderón 5 \\ 1 Facultad de Ingeniería Civil-Xalapa, Universidad Veracruzana, Lomas del Estadio S/N, Zona Universitaria, \\ C.P. 91000 Xalapa, Veracruz, Mexico \\ 2 National Center for Education and Research on Corrosion and Materials Performance, NCERCAMP-UA, \\ Dept. Chemical, Biomolecular, and Corrosion Engineering, The University of Akron, 302 E Buchtel Ave, \\ Akron, OH 44325-3906, USA; dbastidas@uakron.edu \\ 3 Facultad de Ingeniería Civil—Unidad Torreón, UADEC, C.P. 27276 Torreón, Mexico; grey.shg@gmail.com \\ 4 FIC., Universidad Autónoma de Nuevo León, Ave. Pedro de Alba S/N, Ciudad Universitaria, \\ C.P. 66455 San Nicolás de los Garza, Mexico; jmmr.rangel@gmail.com \\ 5 FIME-CIIIA, Universidad Autónoma de Nuevo León, Av. Universidad S/N, Ciudad Universitaria, \\ C.P. 66455 San Nicolás de los Garza, Mexico; citlalli.gaona@gmail.com (C.G.-T.); \\ falmeraya.uanl.ciiia@gmail.com (F.A.-C.) \\ 6 National Centre for Metallurgical Research (CENIM), CSIC, Ave. Gregorio del Amo 8, 28040 Madrid, Spain; \\ bastidas@cenim.csic.es \\ * Correspondence: mbaltazar@uv.mx; Tel.: +52-2282-5252-94
}

Received: 12 October 2019; Accepted: 25 November 2019; Published: 3 December 2019

\begin{abstract}
The use of supplementary cementitious materials such as fly ash, slag, and silica fume improve reinforced concrete corrosion performance, while decreasing cost and reducing environmental impact compared to ordinary Portland cement. In this study, the corrosion behavior of AISI 1018 carbon steel (CS) and AISI 304 stainless steel (SS) reinforcements was studied for 365 days. Three different concrete mixtures were tested: 100\% CPC (composite Portland cement), $80 \%$ CPC and $20 \%$ silica fume (SF), and $80 \%$ CPC and $20 \%$ fly ash (FA). The concrete mixtures were designed according to the ACI 211.1 standard. The reinforced concrete specimens were immersed in a $3.5 \mathrm{wt} . \% \mathrm{NaCl}$ test solution to simulate a marine environment. Corrosion monitoring was evaluated using the corrosion potential ( $E_{\text {corr }}$ ) according to ASTM C876 and the linear polarization resistance (LPR) according to ASTM G59. The results show that AISI 304 SS reinforcements yielded the best corrosion behavior, with $E_{\text {corr }}$ values mainly pertaining to the region of $10 \%$ probability of corrosion, and corrosion current density $\left(i_{\text {corr }}\right)$ values indicating passivity after 105 days of experimentation and low probability of corrosion for the remainder of the test period.
\end{abstract}

Keywords: concrete; concrete admixtures; corrosion; marine environment; silica fume; fly ash

\section{Introduction}

Due to its relatively low cost and high compressive resistance capability, reinforced concrete is frequently used as a construction material worldwide. However, several aggressive agents found in the environment degrade steel reinforcements, cement, and concrete [1]. Corrosion of steel embedded in concrete was extensively studied since the 1950s, and, in the last 30 years, research concentrated on minimizing the steel corrosion rate. Researchers studying this phenomenon reported a great number 
of different approaches. Current trends focus on innovation in concrete technology, finding alternative materials to composite Portland cement (CPC), the use of different reinforcing steels, the use of corrosion inhibitors, and the impact of the exposure environment, such as marine or urban, both natural and simulated [2-6].

According to the literature, the external, non-structural causes that usually affect the durability of concrete structures are mainly a result of their exposure and service conditions. The service lifetime of a reinforced concrete structure can be reduced by corrosion of the embedded reinforcing steel due to aggressive agents from the environment [7]; one of the main causes is chloride ions. Steel rebars inside reinforced concrete structures (RCS) are susceptible to corrosion when the permeation of chloride from de-icing salts, marine aerosols, or sea water, if they are fully or partially submerged, exceeds a chloride threshold level (CTL) at the steel surface [8,9]. In the case of Mexico, data that can give an idea of losses due to corrosion are unfortunately not available, yet this country has more than $10,000 \mathrm{~km}$ of coastline where there are many reinforced concrete structures susceptible to corrosion damage. However, the total direct cost of corrosion in the United States (US) was determined to be $\$ 276$ billion per year, which is $3.1 \%$ of the US gross domestic product (GDP) [10].

Supplementary cementitious materials (SCMs) such as silica fume (SF), fly ash (FA), and rice husk ash (RHA) are commonly used in concrete formulations around the world [11,12] for different economic and environmental reasons. Moreover, FA particles react with calcium hydroxide to produce hydration products that strongly decrease the concrete porosity [13]. Another type of waste by-product additive exhibiting good results is blended, lime-stabilized drilling mud and cement [14-16]. The recycling of these products in concrete production has positive environmental effects, minimizing problems associated with their disposal [17]. In the last 20-30 years, sugar-cane bagasse ash (SCBA), an agro-industrial waste by-product, was used with great success as a partial substitute of CPC in concrete and showed benefits against corrosion $[18,19]$.

Silica fume was in use in the concrete industry for over 20 years. The silica fume reacts with calcium hydroxide in the presence of water to form cementitious compounds consisting of calcium silicate hydrate. The incorporation of silica fume in concrete improves its strength and durability characteristics. It is also reported that silica fume was successfully used to produce chemically resistant concrete with very high strength and low permeability. Several researchers showed that the addition of silica fume significantly reduces permeability [20]; however, an investigation reported that the use of 10\% silica fume as cement replacement material in producing 70-MPa concrete can have a beneficial effect in terms of reduced corrosion rate. Adverse effects may result from using silica fume at a higher replacement level of $20 \%$ [21].

The use of an industrial waste by-product as a pozzolanic additive in concrete structures, mainly the use of fly ash (FA), was studied extensively around the world. FA is a by-product of the combustion of coal in thermal power plants and is gathered by electrostatic precipitators from the combustion gases before they are discharged into the atmosphere. Only flying particles produced from the burning of the coal are attracted to the precipitators. Most of the FA is formed by silica- and alumina-rich particles with only a small amount of unburnt coal particles. As a result, FA reacts effectively with the concrete portlandite to form more dense and resistant cementitious products, improving in this manner the long-term mechanical and durability properties of concrete [22].

Results on FA research showed that its presence in concrete improves the workability of mortars and concretes in their fresh state. In their hardened state, the presence of FA also improves structural properties such as compressive strength; however, this improvement occurs at a later stage than in the mortars and concretes without FA [23].

The aim of this work was to study the corrosion behavior of reinforced concrete made with partial replacement of CPC, using 20\% SF or $20 \% \mathrm{FA}$ and the remaining $80 \%$ CPC. A reinforced concrete made with $100 \%$ CPC was used as a control sample. Two types of steel reinforcements were studied, conventional AISI 1018 carbon steel (CS) and austenitic AISI 304 stainless steel (SS). The reinforced concrete specimens were immersed in a $3.5 \% \mathrm{NaCl}$ solution for up to 365 days. 


\section{Materials and Methods}

Three different concrete mixtures manufactured using type 30R CPC according to the NMX C 414 standard [24] and partial replacement of CPC by SF or FA industrial waste by-products were studied. The first concrete mixture was made with $100 \%$ CPC, the second contained $80 \%$ CPC and $20 \%$ $\mathrm{SF}$, and the third contained $80 \% \mathrm{CPC}$ and $20 \% \mathrm{FA}$. The concrete mixtures were designed according to the ACI 211.1 standard [25] to obtain a compressive strength of $\mathrm{F}^{\prime} \mathrm{C}=35.7 \mathrm{MPa}$. To determine the compressive strength of the three concrete mixtures evaluated in the present investigation, cylindrical specimens of $15 \mathrm{~cm}$ in diameter and $30 \mathrm{~cm}$ in height were used, and the test was performed according to the NMX-C-083-ONNCCE-2014 standard [26]. The tests to determine the physical characteristics of the aggregates used to manufacture the concrete mixtures were performed according to the following ASTM standards: ASTM C-127-15 (Standard Test Method for Relative Density (Specific Gravity) and Absorption of Coarse Aggregate) [27], ASTM C-128-15 (Standard Test Method for Relative Density (Specific Gravity) and Absorption of Fine Aggregate) [28], ASTM C29/C29M-07 (Standard Test Method for Bulk Density (Unit Weight) and Voids in Aggregate) [29], and ASTM C33/C33M-16e1 (Standard Specification for Concrete Aggregates) to determine the fineness modulus and maximum aggregate size [30]. All of the results of the aforementioned tests are required to meet the ACI 211.1 standard.

Table 1 details the physical characteristics of the aggregates, and Table 2 shows the amounts of cement, water, and aggregates used in each of the three different concrete mixtures, obtained according to the ACI standard.

Table 1. Physical characteristics of the aggregates.

\begin{tabular}{cccccc}
\hline Aggregates & $\begin{array}{c}\text { Relative Density } \\
\text { (Specific Gravity) }\end{array}$ & $\begin{array}{c}\text { Bulk Density (Unit } \\
\text { Weight) } \mathbf{( k g / \mathbf { m } ^ { 3 } )}\end{array}$ & $\begin{array}{c}\text { Absorption } \\
\mathbf{( \% )}\end{array}$ & $\begin{array}{c}\text { Fineness } \\
\text { Modulus }\end{array}$ & $\begin{array}{c}\text { Maximum Aggregate } \\
\text { Size (mm) }\end{array}$ \\
\hline Coarse (gravel) & 2.32 & 1391 & 5.45 & --- & 19 \\
Fine (sand) & 2.66 & 1237 & 1.97 & 2.62 & - - \\
\hline
\end{tabular}

Table 2. Proportioning of three concrete mixtures $1 \mathrm{~m}^{3}\left(\mathrm{~F}^{\prime} \mathrm{c}=35.7 \mathrm{MPa}\right)$.

\begin{tabular}{cccc}
\hline Materials & CPC 30R, kg (4AN, 4AI) & $\begin{array}{c}\text { Silica Fume (SF), } \\
\text { kg (4BN, 4BI) }\end{array}$ & $\begin{array}{c}\text { Fly Ash (FA), kg (4CN, } \\
\text { 4CI) }\end{array}$ \\
\hline Cement & 410 & 328 & 328 \\
Partial substitute & 0 & 82 & 82 \\
Water & 205 & 205 & 205 \\
Coarse aggregate & 890 & 890 & 890 \\
Fine aggregate & 838 & 838 & 838 \\
\hline
\end{tabular}

\subsection{Characterization of Fresh and Hardened Concrete}

Physical and mechanical characterization of the fresh and hardened concrete mixtures was performed according to the ASTM C 1064 standard [31], and the NMX C 156 [32], NMX C 162 [33], and NMX C 083 [26] standards. Table 3 shows the results obtained for the three studied mixtures.

Table 3. Physical and mechanical properties of concrete mixture.

\begin{tabular}{cccc}
\hline Test & CPC 30R (4AN, 4AI) & $\begin{array}{c}\text { Silica Fume (SF) } \\
(\mathbf{4 B N}, \mathbf{4 B I})\end{array}$ & Fly Ash (FA) (4CN, 4CI) \\
\hline Temperature, ${ }^{\circ} \mathrm{C}$ & 24.0 & 21.7 & 22.4 \\
Slump, $\mathrm{cm}$ & 4 & 3 & 3 \\
Density, $\mathrm{kg} / \mathrm{m}^{3}$ & 2150 & 2188 & 2173 \\
Compressive strength & 35.9 & 37.1 & 36.6 \\
$\left(\mathrm{~F}^{\prime} \mathrm{C}\right), \mathrm{MPa}(28$ days $)$ & & & \\
\hline
\end{tabular}




\subsection{Concrete Specimens}

Prismatic concrete specimens with dimensions of $15.0 \times 12.0 \times 7.0 \mathrm{~cm}$ were manufactured with two rebars embedded in the concrete. Table 4 shows the chemical composition of the AISI 1018 CS and AISI $304 \mathrm{SS}$, both of which were $15 \mathrm{~cm}$ in length and $0.95 \mathrm{~mm}$ in diameter. Each as-received rebar was partly coated with an anticorrosive paint in order to leave a length of $5 \mathrm{~cm}$ exposed to the concrete environment. The concrete was made with a water-to-cement ratio of 0.50 . The first two specimens were made with 100\% CPC 30R (denoted 4AN (control specimen) and 4AI); the second two specimens were made replacing $20 \%$ by weight of CPC $30 \mathrm{R}$ with SF (denoted $4 \mathrm{BN}$ and $4 \mathrm{BI}$ ); the third two specimens were made replacing $20 \%$ by weight of CPC $30 \mathrm{R}$ with FA (denoted $4 \mathrm{CN}$ and $4 \mathrm{CI}$ ). The specimens were cured according to the NMX-C-159 standard [34] by immersion in water for 27 days. After the curing period, the six reinforced concrete specimens were immersed in a $3.5 \%$ by weight $\mathrm{NaCl}$ solution for 365 days, simulating a marine environment, and they were then subjected to electrochemical tests.

Table 4. Chemical composition (wt.\%) of the reinforcements tested, AISI 1018 carbon steel, and AISI 304 stainless steel.

\begin{tabular}{ccccccccccc}
\hline \multirow{2}{*}{ Steel } & \multicolumn{10}{c}{ Mass, \% } \\
\cline { 2 - 11 } & $\mathbf{C}$ & Si & Mn & P & S & Cr & Ni & Mo & Cu & Fe \\
\hline AISI 1018 & 0.20 & 0.22 & 0.72 & 0.02 & 0.02 & 0.13 & 0.06 & 0.02 & 0.18 & Balance \\
AISI 304 & 0.04 & 0.32 & 1.75 & 0.03 & 0.001 & 18.20 & 8.13 & 0.22 & 0.21 & Balance \\
\hline
\end{tabular}

As indicated above, the nomenclature used to perform the analysis of the results of $E_{c o r r}$ and $i_{c o r r}$ was made up of three characters; the first two characters indicate the type of studied concrete mix, and the third character refers to the reinforcing steel embedded in the concrete mix. The nomenclature used in the present study is as follows:

- $\quad 4 \mathrm{~A}$ indicates the concrete mix with $100 \%$ CPC;

- $4 \mathrm{~B}$ indicates the concrete mix with $80 \% \mathrm{CPC}+20 \% \mathrm{SF}$;

- $4 \mathrm{C}$ indicates the concrete mix with $80 \% \mathrm{CPC}+20 \% \mathrm{FA}$;

- $\quad \mathrm{N}$ indicates rebars of AISI 1018 carbon steel;

- I indicates rebars of AISI 304 stainless steel.

\subsection{Electrochemical Techniques}

A conventional three-electrode cell configuration was used for electrochemical studies. The AISI 1018 CS and AISI 304 SS were used as the working electrode. A standard copper/copper sulfate $\left(\mathrm{Cu} / \mathrm{CuSO}_{4}, \mathrm{CSE}\right)$ and AISI 316 SS plate were used as the reference and counter/auxiliary electrodes (CE or AE), respectively, see Figure 1. Electrochemical measurements were carried out using a Gill-AC potentiostat/galvanostat/ZRA (ACM Instruments, Cark In Cartmel, UK). The linear polarization resistance (LPR) measurements were recorded using a potential sweep rate of $10 \mathrm{mV} / \mathrm{min}$ at a potential scan range between -20 and $+20 \mathrm{mV}$, according to the ASTM G59-97 standard [35]. The half-cell corrosion potential ( $\left.E_{\text {corr }}\right)$ was recorded according to the ASTM C876-15 standard [36]. Corrosion rate $(\mathrm{CR})$ was calculated from the corrosion current density $\left(i_{\text {corr }}\right)$ using the LPR results [37]. 


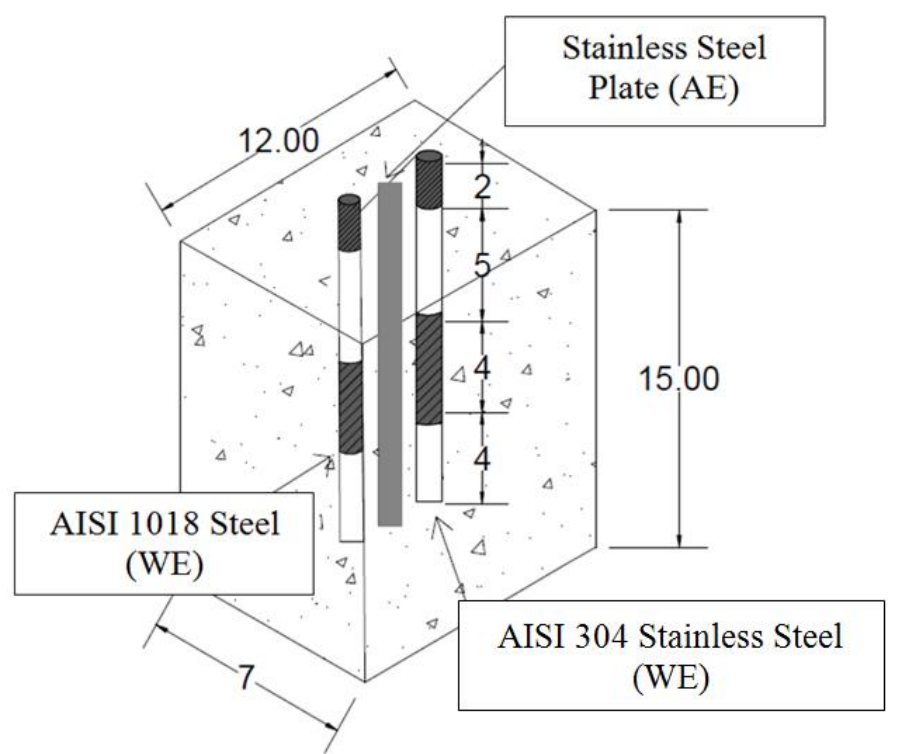

Figure 1. Illustration of the tested specimens: three-electrode corrosion cell and experimental arrangement.

Corrosion experiments were performed by immersion in a $3.5 \mathrm{wt}$ \% $\mathrm{NaCl}$ solution at $25{ }^{\circ} \mathrm{C}$.

Corrosion monitoring $\left(E_{\text {corr }}\right.$ and $\left.i_{\text {corr }}\right)$ was conducted weekly for the reinforced concrete specimens immersed in the $3.5 \mathrm{wt} . \% \mathrm{NaCl}$ solution at room temperature, and the measurements were performed in triplicate. The results were analyzed using Version 4 Analysis specialized software (ACM Instruments, Cark In Cartmel, United Kingdom).

As previously indicated by the authors [38-40], the $i_{\text {corr }}$ and the CR were estimated from the LPR method using the Stern and Geary equation (Equation (1)).

$$
i_{\text {corr }}=\frac{B}{R_{p}},
$$

where B is a constant, equal to $26 \mathrm{mV}$ for active rebar corrosion [41].

To assess the degree of corrosion of the reinforced concrete specimens, the $E_{\text {corr }}$ parameter was used in accordance with the ASTM C 876-15 standard [36], which establishes the criteria that relate the $E_{\text {corr }}$ with the probability of corrosion for the CPC/AISI 1018 CS system, as shown in Table 5 [36,37]. The $i_{\text {corr }}$ values obtained using Equation (1) were used to determine the corrosion rate (CR) of the steels embedded in the concrete mixtures. The criteria used to analyze the $i_{\text {corr }}$ results were based on the state of corrosion of carbon steel in Portland cement-based concrete reported in the literature [41], as shown in Table 6.

Table 5. Probability of corrosion according to the measured corrosion potential $\left(E_{\mathrm{corr}}, \mathrm{mV}_{\mathrm{CSE}}\right)$ versus a $\mathrm{Cu} / \mathrm{CuSO}_{4}$ reference electrode (CSE), for reinforced CPC concrete, using an AISI 1018 carbon steel reinforcement [36,37].

\begin{tabular}{cc}
\hline \multicolumn{2}{c}{ Corrosion Potential, $E_{\text {corr }}\left(\mathbf{m V}_{\mathrm{CSE}}\right)$} \\
\hline$>-200$ & $10 \%$ probability of corrosion \\
$-350<E_{\text {corr }}<-200$ & Uncertainty corrosion \\
$-350<E_{\text {corr }}<-500$ & $90 \%$ probability of corrosion \\
$<-500$ & Severe corrosion \\
\hline
\end{tabular}


Table 6. Level of corrosion in accordance with the corrosion current density $\left(i_{\text {corr }}\right)$ [41].

\begin{tabular}{cc}
\hline Corrosion Rate, $\boldsymbol{i}_{\text {corr }}\left(\boldsymbol{\mu} \mathbf{A} / \mathbf{c m}^{2}\right)$ & Corrosion Level \\
\hline$<0.1$ & Negligible (passivity) \\
$0.1<i_{\text {corr }}<0.5$ & Low corrosion \\
$0.5<i_{\text {corr }}<1$ & Moderate corrosion \\
$>1$ & High corrosion \\
\hline
\end{tabular}

\section{Results and Discussion}

\subsection{Corrosion Potential}

Figure 2 shows $E_{\text {corr }}$ versus exposure time of AISI 1018 CS embedded in concrete for specimen $4 \mathrm{AN}(100 \% \mathrm{CPC})$ (control specimen), specimen 4BN $(80 \% \mathrm{CPC}+20 \% \mathrm{SF})$, and specimen $4 \mathrm{CN}(80 \%$ $\mathrm{CPC}+20 \% \mathrm{SF}$ ). The evolution of $E_{\text {corr }}$ with time for $4 \mathrm{AN}$ (control specimen) was analyzed according to

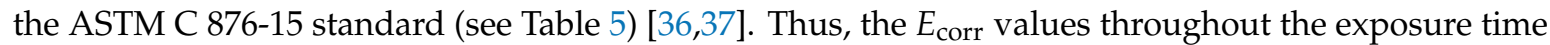
were in the severe corrosion region, with values from $-580 \mathrm{mV}$ to $-480 \mathrm{mV}$ vs. CSE from day 60 to 180.

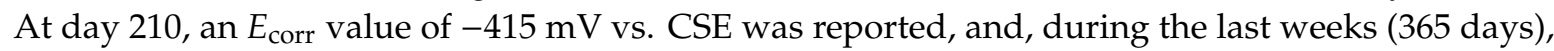
$E_{\text {corr }}$ tended toward a more active value, $-550 \mathrm{mV}$ vs. CSE, in agreement with the literature [42], reporting that reinforced concrete exposed to complete or partial immersion in $3.5 \% \mathrm{NaCl}$ solution

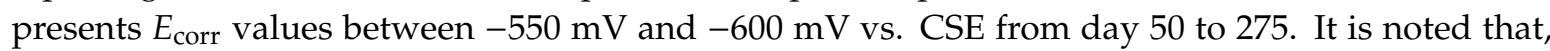
in the referenced study, a concrete specimen with 15\% FA was evaluated [42], presenting an $E_{\text {corr }}$ value of $-400 \mathrm{mV}$ vs. CSE for 125 days of experimentation.

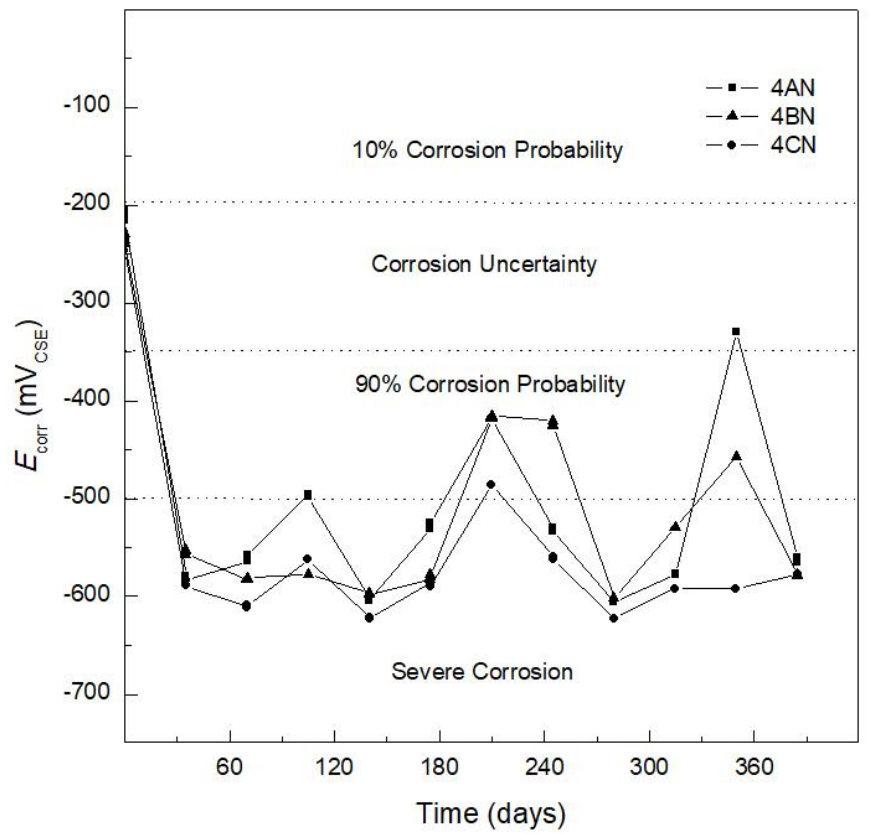

Figure 2. Corrosion potential ( $\left.E_{\text {corr }}\right)$ versus time for AISI 1018 carbon steel embedded in $100 \%$ composite Portland cement (CPC) (specimen 4AN), $80 \%$ CPC + 20\% silica fume (SF) (specimen 4BN), and $80 \%$ $\mathrm{CPC}+20 \%$ fly ash (FA) (specimen $4 \mathrm{CN})$.

It was considered that the corrosion criteria $\left(E_{\text {corr }}\right)$ indicated in Table 5 could be used to analyze the different systems in the present study and an AISI 304 SS reinforcement. Figure 2 shows that

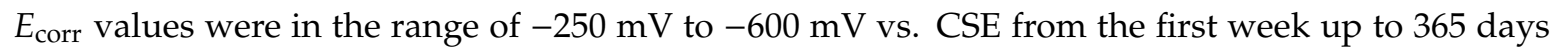
of immersion in $3.5 \mathrm{wt}$ \% NaCl solution. The samples made with AISI $1018 \mathrm{CS}$ and SF (specimen $4 \mathrm{BN}$ ) or FA (specimen 4CN) showed severe corrosion and similar behavior to those made with $100 \%$

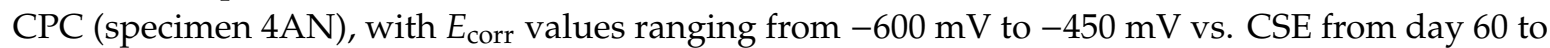


210. For the final weeks ( 360 days), $E_{\text {corr }}$ values remained between $-380 \mathrm{mV}$ and $-480 \mathrm{mV}$ vs. CSE for specimens $4 \mathrm{AN}$ and $4 \mathrm{BN}$ (not presenting severe corrosion) and at a value of $-600 \mathrm{mV}$ vs. CSE for specimen $4 \mathrm{CN}$ (indicating severe corrosion). At the end of the experiment (385 days), the three specimens showed the probability of severe corrosion.

Concrete specimens reinforced with AISI 304 SS (Figure 3) made with 100\% CPC (specimen 4AI), $80 \% \mathrm{CPC}+20 \% \mathrm{SF}$ (specimen $4 \mathrm{BI}$ ), and $80 \% \mathrm{CPC}+20 \% \mathrm{FA}$ (specimen $4 \mathrm{CI}$ ) showed that, during the first weeks (curing step) until day 180, the three specimens presented a $10 \%$ probability of corrosion, with $E_{\text {corr }}>-200 \mathrm{mV}$ vs. CSE. Specimen $4 \mathrm{BI}$ presented an uncertain corrosion probability from day 210

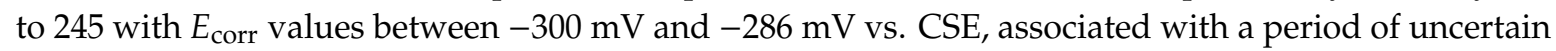
corrosion probability or small rupture (initiation of pitting corrosion) of the passive layer [43-47]. From day 300 to 360 , a passivation process was generated, with $E_{\text {corr }}$ vales of $-200 \mathrm{mV}$ vs. CSE.

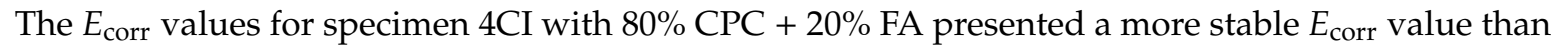
specimens $4 \mathrm{AI}$ and $4 \mathrm{BI}$, from day 30 to 365 , where their $E_{\text {corr }}$ values remained in a range from $-120 \mathrm{mV}$ to $-190 \mathrm{mV}$ vs. CSE, indicating a $10 \%$ probability of corrosion.

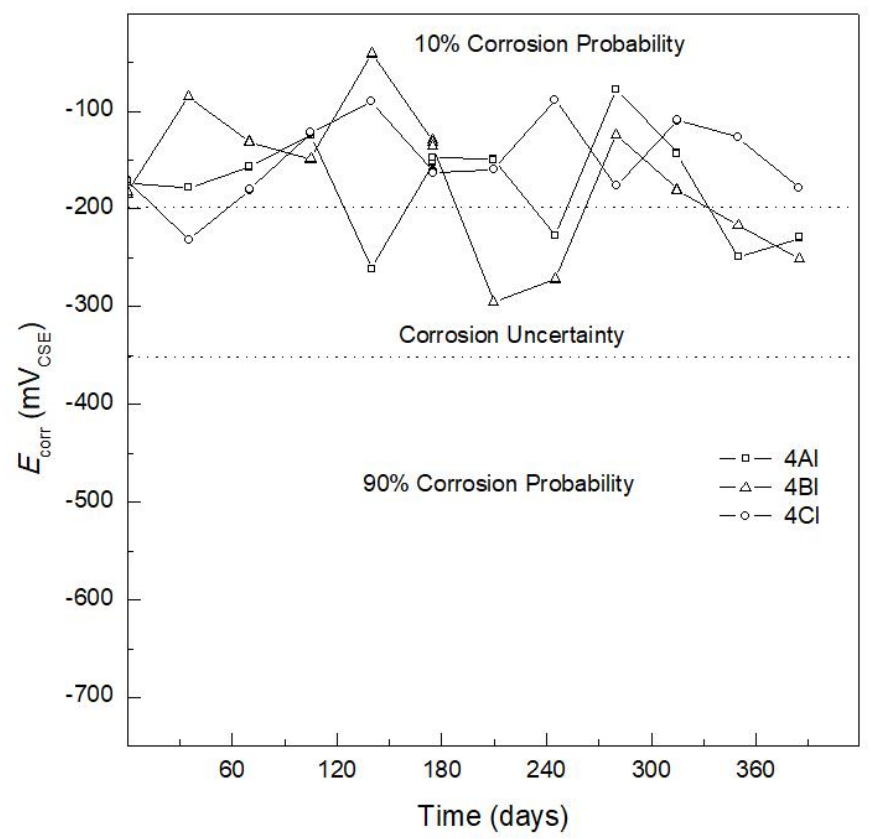

Figure 3. Corrosion potential ( $E_{\text {corr }}$ ) versus time for AISI 304 stainless steel embedded in $100 \%$ CPC (specimen $4 \mathrm{AI}$ ), $80 \% \mathrm{CPC}+20 \% \mathrm{SF}$ (specimen $4 \mathrm{BI}$ ), and $80 \% \mathrm{CPC}+20 \% \mathrm{FA}$ (specimen $4 \mathrm{CI}$ ).

Crouch et al. [48] stated that one of the most attractive properties of FA is its influence on the improvement of durability, which is the result of the reduction in calcium hydroxide, the most soluble of the hydration products, and changes in the pore solution. In the case of specimen $4 \mathrm{BN}$ with $20 \% \mathrm{SF}$, the protection provided to the reinforcing steel against corrosion may be attributed to the SF, which reacts with calcium hydroxide released during the hydration of the cement and forms additional hydrated calcium silicate (C-S-H), which improves the durability and mechanical properties of the concrete [49]. Comparison of the $E_{\text {corr }}$ values in Figures 2 and 3 indicates that a difference in $E_{\text {corr }}$ behavior can be observed, with the AISI 1018 CS reinforced specimens (4AN, 4BN, and 4CN) (Figure 2) exhibiting non-efficient corrosion resistance regardless of the addition of SF or FA. These specimens had more active potentials than $-500 \mathrm{mV}$ vs. CSE, indicating $90 \%$ probability of corrosion and severe corrosion. In contrast, the concrete specimens reinforced with AISI 304 SS (4AI, 4BI, and 4CI) (Figure 3) had $E_{\text {corr }}$ values corresponding to a $10 \%$ probability of corrosion and uncertainty of corrosion. 


\subsection{Corrosion Kinetics}

Figures 4 and 5 show $i_{\text {corr }}$ versus exposure time. Figure 4 shows AISI 1018 CS embedded in concrete for specimen $4 \mathrm{AN}(100 \% \mathrm{CPC})$ (control specimen), specimen $4 \mathrm{BN}(80 \% \mathrm{CPC}+20 \% \mathrm{SF})$, and specimen $4 \mathrm{CN}(80 \% \mathrm{CPC}+20 \% \mathrm{FA})$. The $i_{\text {corr }}$ values obtained using Equation (1) could be used to obtain the corrosion rate (CR). As indicated above, the criteria used to analyze the $i_{\text {corr }}$ results for specimen 4AN (control specimen) (Figure 4) were based on the state of corrosion of carbon steel in Portland cement-based concrete reported in Reference [41], as shown in Table 6. It was considered that the corrosion criteria indicated in Table 6 could be used to interpret the $i_{\text {corr }}$ of the different systems in the present study, for partial replacement of CPC by SF or FA, and for AISI 304 SS reinforcement.

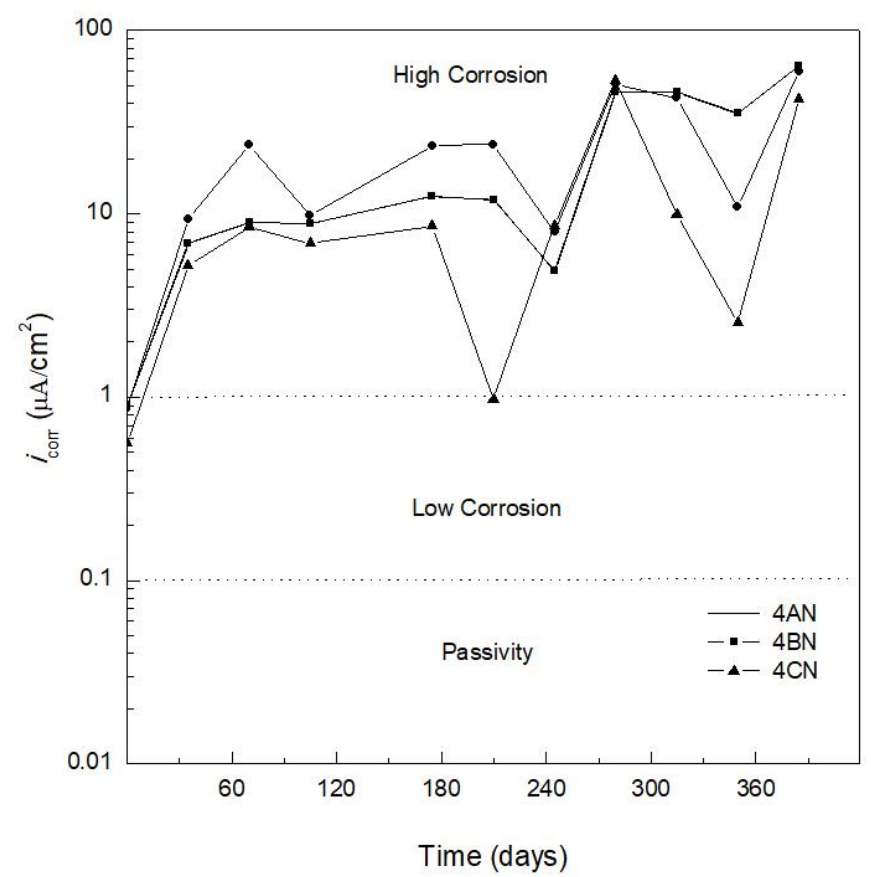

Figure 4. Corrosion current density $\left(i_{\text {corr }}\right)$ versus time for AISI 1018 carbon steel embedded in $100 \%$ CPC (specimen $4 \mathrm{AN}$ ), $80 \% \mathrm{CPC}+20 \% \mathrm{SF}$ (specimen $4 \mathrm{BN}$ ), and $80 \% \mathrm{CPC}+20 \% \mathrm{FA}$ (specimen $4 \mathrm{CN}$ ).

Figure 4 shows $i_{\text {corr }}$ results for the three types of specimens reinforced with AISI 1018 CS. During the curing period, $i_{\text {corr }}$ values from 1 to $3 \mu \mathrm{A} / \mathrm{cm}^{2}$ could be observed. In general, it was seen that the

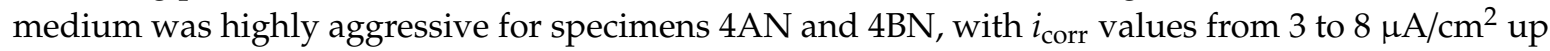
to day 105 , decreasing to $0.8 \mu \mathrm{A} / \mathrm{cm}^{2}$ for specimen $4 \mathrm{BN}$ at day 210 because of the passivation of the AISI 1018 CS reinforcement. Specimen $4 \mathrm{AN}$ presented a decrease of $i_{\text {corr }}$ from 12 to $3 \mu \mathrm{A} / \mathrm{cm}^{2}$ from day 140 to 245.

The specimen containing 20\% FA (specimen 4CN) showed a tendency toward more active $i_{\text {corr }}$ values than specimens $4 \mathrm{AN}$ and $4 \mathrm{BN}$ until day 280 , where the corrosion behavior was similar to that of specimen $4 \mathrm{AN}$, with values above $10 \mu \mathrm{A} / \mathrm{cm}^{2}$ indicating high corrosion. Concrete specimens reinforced with the AISI $1018 \mathrm{CS}$ presented critical $i_{\text {corr }}$ values above $10 \mu \mathrm{A} / \mathrm{cm}^{2}$; this corrosive aggressiveness to reinforced concrete was also demonstrated in soils with a concentration of $3 \mathrm{wt} . \% \mathrm{NaCl}$, presenting, for the reinforcing steel AISI $1018 \mathrm{CS}$, values of $i_{\text {corr }}$ between $3.3 \mu \mathrm{A} / \mathrm{cm}^{2}$ and $3.6 \mu \mathrm{A} / \mathrm{cm}^{2}$ after 260 days of exposure to the soil environment [50]. 


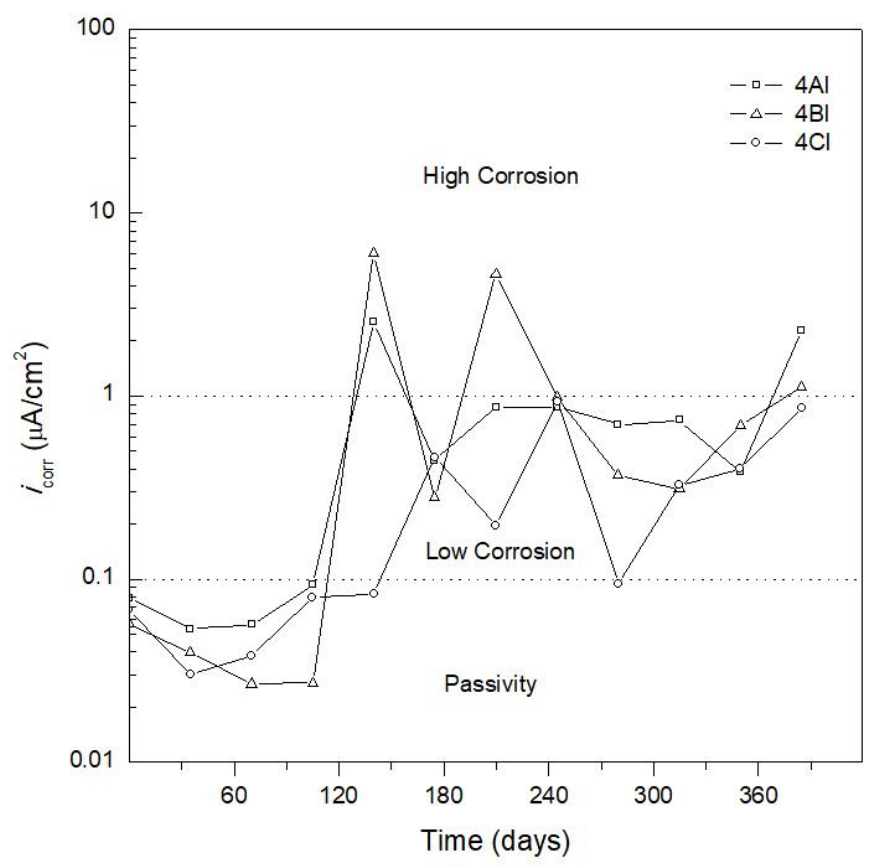

Figure 5. Corrosion current density $\left(i_{\text {corr }}\right)$ versus time for AISI 304 stainless steel embedded in $100 \%$ CPC (specimen 4AI), 80\% CPC + 20\% SF (specimen 4BI), and 80\% CPC + 20\% FA (specimen 4CI).

Figure 5 shows $i_{\text {corr }}$ results for AISI 304 SS embedded in concrete for specimen $4 \mathrm{AI}$ (100\% CPC), specimen $4 \mathrm{BI}(80 \% \mathrm{CPC}+20 \% \mathrm{SF})$, and specimen $4 \mathrm{CI}(80 \% \mathrm{CPC}+20 \% \mathrm{FA})$. The $i_{\text {corr }}$ results for AISI 304 SS showed lower values than for the AISI 1018 CS reinforced specimens (see Figure 4). The specimen made with concrete containing 100\% CPC (specimen $4 \mathrm{AI}$ ) had an $i_{\text {corr }}$ of less than $0.1 \mu \mathrm{A} / \mathrm{cm}^{2}$ until day 105; then, at day 140, it was depassivated with an $i_{\text {corr }}$ of $2 \mu \mathrm{A} / \mathrm{cm}^{2}$. From day 175 to 350, it was in the passive state, presenting $i_{\text {corr }}$ values lower than $1 \mu \mathrm{A} / \mathrm{cm}^{2}$, thus indicating a low corrosion level. It was reported that the passive film formed on AISI 304 SS consists of a duplex layer structure, with an inner layer of chromium oxide covered by an iron-oxide outer layer $[43,44,47]$. In the alkaline environment of the present study, the high Ni content of the AISI 304 SS reinforcement ( $8.13 \mathrm{wt} . \%)$ may have contributed to the corrosion resistance [46].

In the last monitoring period (365-385 days), specimen 4AI manufactured with AISI 304 SS presented an $i_{\text {corr }}$ value of $3 \mu \mathrm{A} / \mathrm{cm}^{2}$ (see Figure 5), showing a benefit in accordance with Bautista et al. [51], indicating that the use of stainless steel in environments with high chloride content is one of the only viable options for achieving more durable reinforced concrete structures. Knudsen et al. [52] also noted that the intelligent use of stainless steel is advisable to repair damaged structures in coastal zones and is a cost-effective option. For a conventional building of 40 flats $\left(\sim 80 \mathrm{~m}^{2}\right.$ each) the use of AISI 304 SS instead of the conventional AISI 1018 CS had an additional structure cost of the order of $5-10 \%$ [53].

Specimen 4BI with $20 \%$ SF showed better corrosion behavior than specimen $4 \mathrm{AI}$ manufactured with $100 \%$ CPC, with $i_{\text {corr }}$ values of $0.03 \mu \mathrm{A} / \mathrm{cm}^{2}$ until day 105 and less than $1 \mu \mathrm{A} / \mathrm{cm}^{2}$ from day 280 to 350 . Specimen $4 \mathrm{CI}$ containing $20 \%$ FA exhibited similar corrosion behavior to specimen 4BI,

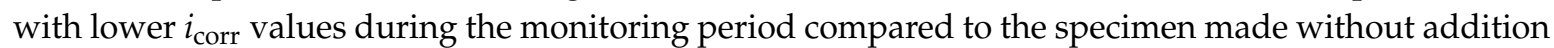
of admixtures (specimen 4AI). A comparison between the specimens reinforced with AISI 1018 CS and AISI 304 SS (see Figures 4 and 5), embedded in concrete without addition and with a mixture of $20 \%$ SF or FA, indicates that, after 385 days of immersion in $3.5 \mathrm{wt} . \% \mathrm{NaCl}$ solution, there was a benefit in terms of corrosion behavior in using the specimens reinforced with AISI 304 SS rather than with AISI 1018 CS. This benefit was further increased by partially replacing CPC with SF or FA, whereby the specimens made with SF showed better corrosion behavior. 


\section{Conclusions}

The three specimens made with and without replacement of CPC by SF or FA (SCMs) reinforced with AISI $1018 \mathrm{CS}$ (specimens $4 \mathrm{AN}, 4 \mathrm{BN}$, and $4 \mathrm{CN}$ ) showed $E_{\text {corr }}$ values indicating severe corrosion for 365 days of experimentation. The $i_{\text {corr }}$ values were higher than $3 \mu \mathrm{A} / \mathrm{cm}^{2}$ for the specimens made with SF and FA (specimens $4 \mathrm{BN}$ and $4 \mathrm{CN}$ ), while the specimen without the addition of mineral additives (specimen $4 \mathrm{AN}$ ) showed values higher than $10 \mu \mathrm{A} / \mathrm{cm}^{2}$. Given this high $i_{\text {corr }}$ value, it is considered that SF and FA afford no significant corrosion protection for AISI 1018 CS under the conditions of the present research. The use of supplementary cementitious materials (SCMs) such as silica fume (substitution in $20 \%$ of CPC) could contribute to the reduction of the use of Portland cement (PC).

The specimens manufactured with SF and AISI 304 SS reinforcement presented $E_{\text {corr }}$ values that indicated a $10 \%$ probability corrosion, and $i_{\text {corr }}$ values that indicated passivity of the reinforcement in the first 105 days. Values of $i_{\text {corr }}$ from 105 to 365 days showed a low corrosion, meaning that the critical chloride threshold value was not reached, where SF and FA have a strong influence due to their capability to decrease the concrete porosity, thus lowering the permeability of chloride ions. The concrete specimens reinforced with AISI 304 SS and immersed in $3.5 \mathrm{wt} . \% \mathrm{NaCl}$ solution showed better corrosion protection than those with AISI 1018 CS reinforcements. The benefit of using AISI 304 SS was increased by partially replacing CPC with SF or FA, and the specimens made with SF afforded better corrosion behavior. These mixtures can be considered as durable green reinforced concrete due to the corrosion protection they presented in comparison to the specimens reinforced with AISI 1018 CS. In conclusion, the $20 \%$ replacement of CPC by SF or FA in concrete exposed to a marine environment and reinforced with AISI 304 SS increased the RCS durability.

Author Contributions: Conceptualization M.A.B.-Z., D.M.B. and F.A.-C.; Methodology, G.S.-H. and J.M.M.-R.; Data Curation, C.G.-T. and J.M.B.; Writing-Review and Editing, M.A.B.-Z., D.M.B. and F.A.-C.

Funding: This research was funded by PRODEP for the support granted by the SEP, to the Academic Body UV-CA-458 "Sustainability and Durability of Materials for Civil Infrastructure", within the framework of the 2018 Call for the Strengthening of Academic Bodies with IDCA 28593. Funding support from The University of Akron, Fellowship Program FRC-207367.

Acknowledgments: The authors thank PRODEP for the support granted by the SEP, to the Academic Body UV-CA-458 "Sustainability and Durability of Materials for Civil Infrastructure", within the framework of the 2018 Call for the Strengthening of Academic Bodies with IDCA 28593. D.M. Bastidas acknowledges funding support from The University of Akron, Fellowship Program FRC-207367. The authors also thank S. Márquez-Montero, M.I. Velásquez-Hernández and P.J. Gallego-Quintana for the technical support.

Conflicts of Interest: The authors declare no conflicts of interest.

\section{References}

1. Campos Silva, H.G.; Garces Terradillos, P.; Zornoza, E.; Mendoza-Rangel, J.M.; Castro-Borges, P.; Juarez Alvarado, C.A. Improving Sustainability through Corrosion Resistance of Reinforced Concrete by Using a Manufactured Blended Cement and Fly Ash. Sustainability 2018, 10, 2004. [CrossRef]

2. Melchers, R.E.; Li, C.Q. Reinforcement corrosion initiation and activation times in concrete structures exposed to severe marine environments. Cem. Concr. Res. 2009, 39, 1068-1076. [CrossRef]

3. Baltazar, M.A.; Santiago, G.; Moreno, V.M.; Croche, R.; De la Garza, M.; Estupiñan, F.; Zambrano, P.; Gaona, G. Electrochemical behaviour of galvanized steel embedded in concrete exposed to sand contaminated with NaCl. Int. J. Electrochem. Sci. 2016, 11, 10306-10319. [CrossRef]

4. Pradhan, B. Corrosion behavior of steel reinforcement in concrete exposed to composite chloride-Sulfate environment. Constr. Build. Mater. 2014, 72, 398-410. [CrossRef]

5. Santiago, G.; Baltazar, M.A.; Galván, R.; López, L.; Zapata, F.; Zambrano, P.; Gaona, C.; Almeraya, F. Electrochemical Evaluation of Reinforcement Concrete Exposed to Soil Type SP Contaminated with Sulphates. Int. J. Electrochem. Sci. 2016, 11, 4850-4864. [CrossRef]

6. Troconis de Rincón, O.; Montenegro, J.C.; Vera, R.; Carvajal, A.M.; De Gutiérrez, R.M.; Del Vasto, S.; Saborio, E.; Torres-Acosta, A.; Pérez-Quiroz, J.; Martínez-Madrid, M.; et al. Reinforced Concrete Durability in Marine Environments DURACON Project: Long-Term Exposure. Corrosion 2016, 72, 824-833. [CrossRef] 
7. Caré, S.; Raharinaivo, A. Influence of impressed current on the initiation of damage in reinforced mortar due to corrosion of embedded Steel. Cem. Concr. Res. 2007, 37, 1598-1612. [CrossRef]

8. Ann, K.Y.; Song, H.W. Chloride threshold level for corrosion of steel in concrete. Corros. Sci. 2007, 49, 4113-4133. [CrossRef]

9. Medina, E.; Medina, J.M.; Cobo, A.; Bastidas, D.M. Evaluation of mechanical and structural behavior of austenitic duplex stainless steel reinforcements. Constr. Build. Mater. 2015, 78, 1-7. [CrossRef]

10. Yunovich, M.; Thompson, N.G. Corrosion of Highway Bridges: Economic Impact and Control Methodologies. Concr. Int. 2003, 25, 52-57.

11. Criado, M.; Fernández-Jiménez, A.; Palomo, A. Alkali activation of fly ash: Effect of $\mathrm{SiO}_{2} / \mathrm{Na}_{2} \mathrm{O}$ ratio Part I: FTIR study. Microporous Mesoporous Mat. 2007, 106, 180-191. [CrossRef]

12. Santiago-Hurtado, G.; Baltazar-Zamora, M.A.; Olguín-Coca, J.; López, L.D.; Galván-Martínez, R.; Ríos-Juárez, A.; Gaona-Tiburcio, C.; Almeraya-Calderón, F. Electrochemical Evaluation of a Stainless Steel as Reinforcement in Sustainable Concrete Exposed to Chlorides. Int. J. Electrochem. Sci. 2016, 11, 2994-3006. [CrossRef]

13. Choi, Y.S.; Kim, J.G.; Lee, K.M. Corrosion behavior of steel bar embedded in fly ash concrete. Corros. Sci. 2006, 48, 1733-1745. [CrossRef]

14. Amorin, R.; Opoku, P.; Osei, E. Evaluation of blended lime-stabilised spent synthetic-based drilling mud and cement for oil well cementing operations. Adv. Geo Energy Res. 2019, 3, 141-148. [CrossRef]

15. Larki, O.; Norouzi Apourvari, S.; Schaffie, M.; Farazmand, R.A. New formulation for lightweight oil well cement slurry using a natural pozzolan. Adv. Geo Energy Res. 2019, 3, 242-249. [CrossRef]

16. Broni-Bediako, E.; Amorin, R. Experimental study on the effects of cement contamination in a water based mud. Adv. Geo Energy Res. 2019, 3, 314-319. [CrossRef]

17. Cordeiro, G.C.; Toledo-Filho, R.D.; Tavares, L.M.; Fairbairn, E.M.R. Pozzolanic activity and filler effect of sugar cane bagasse ash in Portland cement and lime mortars. Cem. Concr. Compos. 2008, 30, 410-418. [CrossRef]

18. Cordeiro, G.C.; Toledo-Filho, R.D.; Tavares, L.M.; Fairbairn, E.M.R. Ultrafine grinding of sugar cane bagasse ash for application as pozzolanic admixture in concrete. Cem. Concr. Res. 2009, 39, 110-115. [CrossRef]

19. Landa-Gómez, A.E.; Croche, R.; Márquez-Montero, S.; Villegas Apaez, R.; Ariza-Figueroa, H.A.; Estupiñan López, F.; Gaona Tiburcio, G.; Almeraya Calderón, F.; Baltazar-Zamora, M.A. Corrosion Behavior 304 and 316 Stainless Steel as Reinforcement in Sustainable Concrete Based on Sugar Cane Bagasse Ash Exposed to $\mathrm{Na}_{2} \mathrm{SO}_{4}$. ECS Trans. 2018, 84, 179-188. [CrossRef]

20. Muralidharan, S.; Parande, A.K.; Saraswathy, V.; Kumar, K.; Palaniswamy, N. Corrosion of steel in concrete with and without silica fume. Zaštita Mater. 2008, 49, 3-8.

21. Cao, H.T.; Sirivivatnanon, V. Corrosion of steel in concrete with and without silica fume. Cem. Concr. Res. 1991, 36, 1922-1930. [CrossRef]

22. Malhotra, V.M.; Ramezanianpour, A.A. Fly Ash in Concrete, 2nd ed.; Natural Resources CANMET: Hamilton, ON, Canada, 1994.

23. Franco-Luján, V.A.; Maldonado-García, M.A.; Mendoza-Rangel, J.M.; Montes-García, P. Chloride-induced reinforcing steel corrosion in ternary concretes containing fly ash and untreated sugarcane bagasse ash. Constr. Build. Mater. 2019, 198, 608-618. [CrossRef]

24. NMX-C-414-ONNCCE-2014-Industria de la Construcción-Cementantes Hidráulicos-Especificaciones y Métodos de Ensayo; ONNCCE: Ciudad de México, Mexico, 2014.

25. ACI 211.1-91 Standard. Standard Practice for Selecting Proportions for Normal, Heavyweight, and Mass Concrete; ACI: Farmington Hills, MI, USA, 2002.

26. NMX-C-083-ONNCCE-2014-Industria de la Construcción-Concreto-Determinación de la Resistencia a la Compresión de Especímenes-Método de Ensayo; ONNCCE: Ciudad de México, Mexico, 2014.

27. ASTM C127-15-Standard Test Method for Relative Density (Specific Gravity) and Absorption of Coarse Aggregate; ASTM International: West Conshohocken, PA, USA, 2015.

28. ASTM C128-15-Standard Test Method for Relative Density (Specific Gravity) and Absorption of Fine Aggregate; ASTM International: West Conshohocken, PA, USA, 2015.

29. ASTM C29/C29M-07-Standard Test Method for Bulk Density ("Unit Weight") and Voids in Aggregate; ASTM International: West Conshohocken, PA, USA, 2007. 
30. ASTM C33/C33M-16e1-Standard Specification for Concrete Aggregates; ASTM International: West Conshohocken, PA, USA, 2016.

31. ASTM C 1064/C1064M-08-Standard Test Method for Temperature of Freshly Mixed Hydraulic-Cement Concrete; ASTM International: West Conshohocken, PA, USA, 2008.

32. NMX-C-156-ONNCCE-2010-Determinación de Revenimiento en Concreto Fresco; ONNCCE: Ciudad de México, Mexico, 2010.

33. NMX-C-162-ONNCCE-2014-Industria de la Construcción-Concreto Hidráulico-Determinación de la Masa Unitaria, Cálculo del Rendimiento y Contenido de Aire del Concreto Fresco por el Método Gravimétrico; ONNCCE: Ciudad de México, Mexico, 2014.

34. NMX-C-159-ONNCCE-2004, Industria de la Construcción-Concreto-Elaboración y Curado de Especímenes en el Laboratorio; ONNCCE: Ciudad de México, Mexico, 2004.

35. ASTM G 59-97 (2014)—Standard Test Method for Conducting Potentiodynamic Polarization Resistance Measurements; ASTM International: West Conshohocken, PA, USA, 2014.

36. ASTM C 876-15 (2015)—Standard Test Method for Corrosion Potentials of Uncoated Reinforcing steel in Concrete; ASTM International: West Conshohocken, PA, USA, 2015.

37. Song, H.W.; Saraswathy, V. Corrosion Monitoring of Reinforced Concrete Structures-A Review. Int. J. Electrochem. Sci. 2007, 2, 1-28.

38. Nuñez, R.; Buelna, J.; Barrios, C.; Gaona, C.; Almeraya, F. Corrosion of Modified Concrete with Sugar Cane Bagasse Ash. Int. J. Corrs. 2012, 12, 1-5.

39. Baltazar, M.A.; Maldonado, M.; Tello, M.; Santiago, G.; Coca, F.; Cedano, A.; Barrios, C.P.; Nuñez, R.; Zambrano, P.; Gaona, C.; et al. Efficiency of Galvanized Steel Embedded in Concrete Previously Contaminated with 2, 3 and $4 \%$ of NaCl. Int. J. Electrochem. Sci. 2012, 7, 2997-3007.

40. Baltazar, M.A.; Santiago, G.; Gaona, C.; Maldonado, M.; Barrios, C.P.; Nunez, R.; Perez, T.; Zambrano, P.; Almeraya, F. Evaluation of the corrosion at early age in reinforced concrete exposed to sulfates. Int. J. Electrochem. Sci. 2012, 7, 588-600.

41. Feliu, S.; González, J.A.; Andrade, C. Electrochemical methods for on-site determinations of corrosion rates of rebars. In Techniques to Assess the Corrosion Activity of Steel Reinforced Concrete Structures; ASTM STP 1276; Berke, N.S., Escalante, E., Nmai, C.K., Whiting, D., Eds.; ASTM International: West Conshohocken, PA, USA, 1996.

42. Montemor, M.F.; Simoes, A.M.P.; Salta, M.M. Effect of fly ash on concrete reinforcement corrosion studied by EIS. Cem. Concr. Compos. 2000, 22, 175-185. [CrossRef]

43. Fajardo, S.; Bastidas, D.M.; Ryan, M.P.; Criado, M.; McPhail, D.S.; Morris, R.J.H.; Bastidas, J.M. Low energy SIMS characterization of passive oxide films formed on a low-nickel stainless steel in alkaline media. Appl. Surf. Sci. 2014, 288, 423-429. [CrossRef]

44. Fajardo, S.; Bastidas, D.M.; Ryan, M.P.; Criado, M.; McPhail, D.S.; Bastidas, J.M. Low-nickel stainless steel passive film in simulated concrete pore solution: A SIMS study. Appl. Surf. Sci. 2010, 256, 6139-6143. [CrossRef]

45. Monticelli, C.; Criado, M.; Fajardo, S.; Bastidas, J.M.; Abbottoni, M.; Balbo, A. Corrosion behavior of low Ni austenitic stainless steel in carbonated chloride-polluted alkali-activated fly ash mortar. Cem. Concr. Res. 2014, 55, 49-58. [CrossRef]

46. Fajardo, S.; Bastidas, D.M.; Criado, M.; Bastidas, J.M. Electrochemical study on the corrosion behavior of a new low-nickel stainless steel in carbonated alkaline solution in the presence of chlorides. Electrochim. Acta 2014, 129, 160-170. [CrossRef]

47. Criado, M.; Bastidas, D.M.; Fajardo, S.; Fernández-Jiménez, A.; Bastidas, J.M. Corrosion behaviour of a new low-nickel stainless steel embedded in activated fly ash mortars. Cem. Concr. Compos. 2011, 33, 644-652. [CrossRef]

48. Crouch, L.K.; Hewitt, R.; Byard, B. High Volume Fly Ash Concrete. In Proceedings of the 2007 World of Coal Ash (WOCA), Covington, KY, USA, 7-10 May 2007; pp. 1-14.

49. Amudhavalli, N.K.; Mathew, J. Effect of silica fume on strength and durability parameters of concrete. Int. J. Eng. Sci. Emerg. Technol. 2012, 3, 28-35.

50. Baltazar, M.A.; Mendoza, J.M.; Croche, R.; Gaona, C.; Hernández, C.; López, L.; Olguín, F.; Almeraya, F. Corrosion Behavior of Galvanized Steel embedded in concrete exposed to soil type MH contaminated with chlorides. Front. Mater. 2019, 6, 257. [CrossRef] 
51. Bautista, A.; Blanco, G.; Velasco, F. Corrosion behavior of low-nickel austenitic stainless steels reinforcements: A comparative study in simulated pore solutions. Cem. Concr. Res. 2006, 36, 1922-1930. [CrossRef]

52. Knudsen, A.; Jensen, F.M.; Klinghoffer, O.; Skovsgaard, T. Cost-effective enhancement of durability of concrete structures by intelligent use of stainless steel reinforcement. In Proceedings of the Conference of Corrosion and Rehabilitation of Reinforced Concrete Structures, Orlando, FL, USA, 7-11 December 1998.

53. Medina, E. Evaluation of Mechanical, Structural and Corrosion Behavior of a New Duplex Low-Nickel Stainless Steel Reinforcement. Ph.D. Thesis, Polytechnic University of Madrid, Madrid, Spain, 2012; pp. 167-180.

(C) 2019 by the authors. Licensee MDPI, Basel, Switzerland. This article is an open access article distributed under the terms and conditions of the Creative Commons Attribution (CC BY) license (http://creativecommons.org/licenses/by/4.0/). 